\title{
Desain Penegakan Hukum Korupsi Partai Politik di Indonesia
}

\author{
Agil Oktaryal, Proborini Hastuti \\ Sekolah Tinggi Hukum Indonesia Jentera, \\ UIN Sunan Kalijaga Yogyakarta \\ agil.oktaryal@pshk.or.id,proborini.hastuti@uin-suka.ac.id
}

\begin{abstract}
The large number of corruption cases whose funds flow to political parties becomes a problem when regulations cannot trap them. This brings awareness to create an ideal law enforcement design against criminal acts of corruption by the political parties. As for the law enforcement design that initiated, namely reducing state financial assistance to the party; prohibition of participating in coming elections; and dissolution of political parties followed by restrictions on the rights of former officials to carry out any political-based activities. This is accompanied by a broad and progressive interpretation by the law enforcers to define political parties as corporations.
\end{abstract}

Keywords: Party, Political, Law, Fund, Design

\begin{abstract}
Abstrak
Banyaknya korupsi yang aliran dananya mengarah pada partai politik menjadi problematika tersendiri ketika regulasi belum mampu menjerat partai politik. Upaya untuk melahirkan desain penegakan hukum yang ideal terhadap tindak pidana korupsi oleh partai politik sangat diperlukan. Penelitian ini bertujuan untuk mengidentifikasi capaian dan tantangan dalam konstruksi penegakan hukum tindak pidana korupsi yang melibatkan partai politik sebagai subjek delik. Kerangka yang dibangun berangkat dari hakikat partai politik dalam negara demokrasi, korupsi (partai) politik, dan korporasi sebagai subjek hukum pidana. Adapun desain penegakan hukum yang digagas yaitu pengurangan bantuan keuangan negara (maksimal 30\% pada 1 tahun anggaran); larangan menjadi peserta pemilu (dilakukan pada penyelenggaraan semua tingkatan pemilihan periode selanjutnya); dan pembubaran partai politik yang diikuti pembatasan hak mantan pengurus untuk melakukan kegiatan berbasis politik termasuk berpindah ke partai lain atau mendirikan partai politik baru. Hal ini harus diiringi dengan tafsir luas dan progresif oleh penegak hukum untuk memaknai partai politik sebagai korporasi.
\end{abstract}

Kata Kunci : Partai, Politik, Hukum, Dana, Desain 


\section{Pendahuluan}

\section{Latar Belakang Masalah}

Partai politik (parpol) yang sejatinya sebagai wadah aspirasi masyarakat, penyambung antara suprastruktur dan infrastruktur politik, semestinya berjalan sinergis. Namun, korupsi yang terjadi membuat apatisme masyarakat dan rasa tidak percaya kian meningkat.

Faktor kebutuhan parpol akan dana besar agar dapat memenangkan pemilu telah mendorong para politisi untuk berlaku korup. Secara umum para politisi di DPR mempunyai empat cara dalam mengumpulkan dana (Junaidi et.al, 2011), pertama, membuat kebijakan yang menguntungkan pihak tertentu; kedua, menyusun rencana proyek dan anggarannya dalam APBN yang kelak akan dikerjakan oleh pihak tertentu; ketiga, menjadi calo tender proyek; dan keempat, meminta imbalan atas pemilihan jabatan publik atau pimpinan Badan Usaha Milik Negara (BUMN).

Perihal kasus korupsi politik, yang perlu menjadi episentrum perhatian adalah subjek korupsi yang selalu berakhir pada oknum-oknum dari parpol, sementara parpol sebagai institusi berbadan hukum seolah mempunyai kekebalan hukum. Sekian banyak oknum parpol yang terjerat kasus korupsi memunculkan ambiguitas, apakah korupsi tersebut murni hanya dilakukan oleh oknum secara pribadi, apakah uangnya tidak mengalir ke parpol, atau memang korupsi tersebut dilakukan secara terorganisasi dan sistematis oleh parpol. Tentunya hal ini menjadi tanda tanya besar terlebih jika penyuapan politik yang dilakukan di parlemen dalam penyusunan legislasi mempunyai nilai rupiah yang tak sedikit dan berimplikasi terhadap kebijakan lanjutan. Tidak sedikit uang yang digelontorkan oleh pemilik modal kepada parpol dalam rangka menggolkan suatu peraturan. Orientasinya agar yang dihasilkan berpihak kepada pemilik modal (political bribery) (Hiariej, 2011).

Berkaca pada tahun 2018 ketika terjadi korupsi proyek Pembangkit Listrik Tenaga Uap (PLTU) Mulut Tambang Riau-1 yang menyeret pengurus Partai Golkar (Eni Maulani) dan mantan Sekjen Partai Golkar (Idrus Marham). Eni mengaku bahwa sebagian uang hasil korupsi mengalir ke panitia Munaslub Partai Golkar saat itu. Indikasi aliran dana tersebut cukup kuat karena ketika itu Partai Golkar mengembalikan uang 700 juta kepada Komisi Pemberantasan Korupsi (KPK) dimana total yang diduga dialirkan berjumlah 2 (dua) milyar (https://www.hukumonline.com/berita/ baca/lt5ba0c9cc5e3cf/mungkinkahpartai-politik-diperlakukan-sebagaikorporasi-dalam-kasus-tipikor?page $=2$ ).

Survei global yang dilakukan Transparency International Indonesia (TII) pada 2014 dan 2017 mengungkapkan bahwa DPR dan lembaga legislatif di bawahnya sebagai lembaga yang paling korup. Hal itupun kembali terbukti ketika terjadi tiga kasus korupsi di tubuh Dewan Perwakilan Rakyat Daerah (DPRD) yang menyita perhatian publik. Korupsi yang dimaksud yaitu korupsi yang dilakukan oleh para anggota DPRD Kota Malang pada tahun 2018, korupsi di lingkungan DPRD Jambi pada tahun 2019 yang menyeret 12 orang anggota DPRD Jambi dan kasus 14 orang anggota DPRD Sumatera Utara yang ditetapkan oleh KPK sebagai tersangka pada awal tahun 2020 (https://www.bbc.com/indonesia/indonesi a-45464288). Dalam refleksi ketiga kasus korupsi yang setipe tersebut, sangat dimungkinkan dana yang dikorupsi juga mengalir ke tubuh parpol, walaupun tentu saja parpol jelas mengingkari dan 
mengatakan hal itu adalah murni kesalahan dari kadernya sebagai oknum.

Namun demikian, desain penegakan hukum tindak pidana korupsi di Indonesia saat ini belum berorientasi pada parpol untuk dapat dijadikan subjek pidana. Tentunya hal ini berimplikasi pada degradasi fungsi parpol yang telah bergeser dari mengusung kepentingan rakyat menjadi pengusung kepentingankepentingan kelompok. Mirisnya lagi, selama ini banyak anggota parpol yang diproses korupsi dan dalam beberapa keterangan menunjukkan jika uang haram itu juga mengalir ke parpol.

Pada akhirnya akan sulit untuk mendikotomikan ketersinggungan antara parpol dan kadernya dalam praktik korupsi politik. Partai politik diposisikan sebagai entitas dominan karena dalam sebagian besar kasus korupsi yang ditelisik oleh KPK melibatkan "orangorang politik" yang notabene adalah para elit parpolnya. Sehingga jelas terlihat benang merah yang mengarah pada pembiayaan aktifitas politik partai atas praktik korupsi yang dilakukan. Praktik rent seeking ini dilakukan oleh hampir semua kader parpol ketika menduduki posisi penting pemerintahan, baik di pusat maupun di daerah (Aspan dan Suwandi, 2020:69).

Sampai saat ini belum pernah ada satupun parpol selaku badan hukum yang dapat dimintai pertanggungjawaban pidana walaupun secara terang parpol ikut menikmati dana hasil korupsi yang dilakukan para kadernya (Wangga, 2018:259). Sehingga pada tataran inilah perlu adanya desain ideal penegakan hukum yang terstruktur, tegas dan mapan terhadap parpol dalam konteks tindak pidana korupsi. Tentunya desain penegakan ini akan diterapkan berjenjang sesuai dengan karakteristik korupsi yang dilakukan supaya selaras dengan idealitas kebijakan pidana dalam bangunan negara hukum.

\section{Rumusan Masalah}

Berdasarkan latar belakang masalah di atas, dapat dirumuskan beberapa permasalahan antara lain:

1. Bagaimana praktik korupsi di Indonesia yang mengarah pada pengaliran dana hasil korupsi ke partai politik?

2. Bagaimana pengaturan penegakan korupsi saat ini dalam mendorong partai politik yang bebas korupsi?

3. Bagaimana konsep dan desain ideal penegakan hukum korupsi partai politik untuk menciptakan partai politik yang bebas korupsi?

\section{Kerangka Teori}

Penelitian ini menggunakan tiga teori untuk membangun kerangka dasar dalam menganalisis permasalahan yang diajukan. Tiga teori yang dimaksud yaitu (1) hakikat partai politik dalam negara demokrasi; (2) korupsi (partai) politik; dan (3) korporasi sebagai subjek hukum pidana. Dalam melihat hubungan korupsi dan politik, Roben Hoddes mendefinisikan korupsi politik sebagai penyalahgunaan kekuasaan oleh pemimpin politik dengan mengakumulasi kekuasaan dan kekayaan serta untuk keuntungan pribadi (Transparancy Internasional, 2004). Korupsi ini berbeda dengan korupsi birokrasi atau korupsi kecil-kecilan dalam pelayanan publik karena pelakunya adalah pejabat politik yang terpilih melalui pemilihan umum yang mendapatkan otoritas untuk mengalokasikan sumberdaya publik dan bertanggungjawab mewakili kepentingan publik. Bahkan, dalam perjalanannya, korupsi menjadi ganjalan setelah reformasi konstitusi, khususnya korupsi yang dilakukan di sektor publik, karena pelakunya mempunyai kekuasaan di 
pemerintahan, parlemen, atau pengadilan. De Coste dalam Indrayana (2008: 146) menamakan korupsi oleh pejabat publik ini sebagai political corruption.

Sementara pembahasan mengenai korporasi menjadi subjek hukum pidana di Indonesia mulai dikenal tahun 1951 dalam UU Penimbunan Barang. Kemudian dalam UU No. 7 Tahun 1955 tentang Tindak Pidana Ekonomi, UU Subversi, UU Narkotika, UU Psikotropika, UU Lingkungan Hidup, UU Tipikor, dan UU TPPU (Muladi dan Priyatno, 2010: 46). Korporasi sebagai subjek hukum pidana di Indonesia hanya dikenal dalam hukum pidana khusus, karena KUHP masih tetap menganut subjek hukum manusia. Secara lebih lengkap korporasi dinilai telah melakukan tindak pidana dapat dilihat keterkaitannya kepada beberapa teori (Ali, 2016:46-47), yaitu teori pelaku fungsional (functioneel daaderschap), teori identifikasi, vicarious liability dan strict liability

Berdasarkan logika yang ada dalam menjerat korporasi (badan hukum) sebagai subjek hukum pidana tersebut, dalam rangka meminta pertanggung jawaban pidana parpol sebagai badan hukum ketika terlibat dalam tindak pidana korupsi, maka logika itu pula yang akan digunakan dalam penelitian ini.

\section{Metode Penelitian}

Penelitian ini menggunakan pendekatan undang-undang (statute appoarch) dan pendekatan kasus (case appoarch). Berbeda dengan penelitian sosial, pendekatan kasus (case approach) dalam penelitian hukum normatif bertujuan untuk mempelajari penerapan norma-norma atau kaidah yang dilakukan dalam praktik hukum (Marzuki, 2008:93). Adapun jenis penelitian ini menggunakan metode penelitian yuridis-normatif atau sering disebut juga penelitian hukum doktrinal (Muhammad, 2004:52).

\section{Pembahasan}

Praktik Korupsi di Indonesia yang Mengarah Pada Pengaliran Dana Hasil Korupsi ke Partai Politik

Saat ini yang perlu menjadi episentrum perhatian ihwal korupsi politik adalah bagaimana parpol sebagai badan hukum bisa dijerat hukum. Tentunya hal ini harus dibuktikan bahwa ada aliran dana hasil korupsi yang mengalir ke kantong parpol. Perlu dipahami juga bahwa korupsi politik tidak hanya dalam bentuk pertukaran uang tetapi juga berupa memperdagangkan pengaruh (trading influence) atau memberikan fasilitas yang meracuni politik dan mengancam demokrasi.

Dari penelusuran yang dilakukan, sepanjang tahun 2004 hingga 2019 terdapat 1152 kasus yang melibatkan pejabat publik dan swasta yang melakukan tindak pidana korupsi. Dari jumlah tersebut, 397 orang di antaranya menduduki jabatan politik, rinciannya 257 orang anggota DPR/DPRD, 21 orang gubernur, dan 119 orang adalah bupati/walikota dan wakil yang notabene hampir keseluruhan berlatar belakang dari parpol (https://www.kpk.go.id/id/ statistik/penindakan/tpk-berdasarkanprofesi-jabatan).

Kasus yang dekat dengan pengaliran dana hasil korupsi ke parpol dapat disebutkan diantaranya, pertama, korupsi yang menjerat Ketua Umum Partai Demokrat Anas Urbaningrum (AU) dalam kasus korupsi proyek pembangunan Pusat Pelatihan, Pendidikan dan Sekolah Olahraga Nasional (P3SON) Hambalang dan berbagai proyek Anggaran Pendapatan dan Belanja Negara (APBN) (https: //www.kpk.go.id/id/ publikasi/penanganan-perkara/inkracht/ 467-inkracht-2015). Dalam kasus ini juga mencuat dugaan adanya aliran dana hasil tindak pidana korupsi ke aktivitas parpol sebagaimana diungkap oleh mantan 
Bendahara Umum Partai Demokrat Muhammad Nazaruddin. Nazaruddin mengaku telah menyerahkan bukti aliran dana proyek Hambalang kepada KPK. Dana itu digunakan untuk membiayai pemenangan Anas Urbaningrum sebagai ketua umum pada Kongres Partai Demokrat 2010 di Bandung (https://nasional.kompas.com/ read/2017/06/12/07010051/upaya.memu tus.aliran.dana.korupsi.ke.partai.politik.?p age $=$ all).

Kasus tersebut memberikan gambaran bagaimana uang hasil korupsi patut diduga mengalir ke tubuh parpol. Pasalnya, saat tindak pidana dilakukan, yang bersangkutan berkedudukan sebagai ketua umum parpol yang barang tentu berkorelasi dengan tugasnya untuk mencari jalan mendanai parpol.

Kedua, korupsi proyek PLTU Mulut Tambang Riau-1 pada tahun 2018 yang menyeret pengurus Partai Golkar (Eni Maulani Saragih), mantan Sekjen Partai Golkar (Idrus Marham) dan Johannes Budisutrisno Kotjo selaku pemegang saham di perusahaan asal Singapura.

Dalam kasus ini, Eni Maulani, yang merupakan anggota Fraksi Partai Golkar, terbukti menerima suap Rp 4,750 miliar dari Kotjo. Eni juga terbukti menerima gratifikasi Rp 5,6 miliar dan 40.000 dollar Singapura. Sebagian besar uang tersebut diberikan oleh pengusaha di bidang minyak dan gas. Menurut hakim, sebagian uang tersebut digunakan Eni untuk membiayai kegiatan partai (https://nasional.kompas.com/read/2019/ 04/24/06590331/perjalanan-kasus-plturiau-1-jerat-eni-maulani-saragih-hinggasofyan-basir?page=all).

Eni juga mengaku bahwa sebagian uang hasil korupsi yang ia peroleh dari Johannes mengalir ke panitia Munaslub Partai Golkar saat itu. Dimana Eni jadi bendahara dalam perhelatan tersebut. Indikasi aliran dana makin kuat karena ketika itu Partai Golkar mengembalikan uang 700 juta kepada KPK dimana total yang diduga dialirkan berjumlah 2 milyar (https://www.hukumonline.com/berita/ba ca/lt5ba0c9cc5e3cf/mungkinkah-partaipolitik-diperlakukan-sebagai-korporasidalam-kasus-tipikor?page=2). Dalam pengembangan perkara ini, KPK juga menjerat mantan Menteri Sosial, Idrus Marham. Menurut hakim, Idrus terbukti menerima suap Rp 2,250 miliar. Saat itu, Idrus mengisi jabatan Ketua Umum Golkar. Idrus juga terbukti berperan atas pemberian uang dari Kotjo yang digunakan untuk membiayai musyawarah nasional luar biasa (Munaslub) Partai Golkar.

Ketiga, korupsi penganggaran dan pengadaan barang/jasa paket pengadaan penerapan KTP Elektronik Tahun Anggaran 2011-2013. Dalam Surat Dakwaan KPK Nomor DAK15/24/02/2017 menujukkan bahwa terdakwa Irman dan Sugiharto merugikan negara hingga $\mathrm{Rp} 2,3$ triliun dalam kasus e-KTP dari total nilai proyek $\mathrm{Rp} \mathrm{5,9} \mathrm{triliun}$ dan memperkaya orang lain yang notabene anggota Komisi II DPR saat itu. Selain ditengarai mengalir ke anggota parpol, uang dugaan korupsi e-KTP juga disebut dalam surat dakwan mengalir ke parpol dengan rincian sebagai berikut:

1) Partai Golkar Rp 150 miliar;

2) Partai Demokrat Rp 150 miliar;

3) Partai Demokrasi Indonesia Perjuangan $\mathrm{Rp} \quad 80$ miliar;

4) Partai lainnya Rp 80 miliar.

Surat Dakwaan tersebut menggambarkan bagaimana tindak pidana korupsi dilakukan. Surat dakwaan memang belum memiliki kekuatan hukum. Namun, untuk kepentingan akademis, dari kasus tersebut tergambar dugaan ada uang hasil korupsi yang dialirkan ke parpol dalam proyek e-KTP. 
Keempat, korupsi yang melibatkan politisi PDI-P Adriansyah. Anggota Fraksi PDI-P itu terbukti menerima gratifikasi dari bos PT Mitra Maju Sukses, Andrew Hidayat, untuk memuluskan izin usaha tambang di Tanah Laut, Kalimantan Selatan. Mantan Bupati Tanah Laut itu mengaku meminta bantuan kepada Manajer Marketing PT MMS Andrew Hidayat, untuk menambah biaya kongres PDI Perjuangan di Bali, 9 April 2015. Adriansyah mengatakan, ia meminta bantuan uang kepada Andrew untuk menambah biaya operasional kongres sejak sebulan sebelum pelaksanaan. Selain itu, dalam surat dakwaan KPK, uang suap yang diterima anggota Komisi V DPR dari Fraksi PDI-P, Damayanti Wisnu Putranti, diketahui digunakan untuk biaya kampanye PDI-P (https:// nasional.kompas.com/read/2017/06/12/0 7010051/upaya.memutus.aliran.dana.koru psi.ke.partai.politik.?page=all).

Kelima, korupsi yang menjerat mantan Menteri Kesehatan, Siti Fadilah Supari. Menurut jaksa, sejumlah uang yang diterima sebagai keuntungan pihak swasta juga mengalir ke rekening pengurus Dewan Pimpinan Pusat Partai Amanat Nasional (DPP PAN). Tak hanya itu, berdasarkan fakta persidangan, aliran uang yang diterima sebagai keuntungan dari perusahaan pelaksana proyek pengadaan alat kesehatan di Kemenkes juga mengalir ke rekening pendiri PAN Amien Rais. Total uang yang diterima Amien sebesar Rp 600 juta.

Keenam, korupsi pembangunan Purbalingga Islamic Center. Bupati Purbalingga nonaktif, Tasdi, saat menjadi saksi dari 4 terdakwa yakni Kepala ULP Pemkab Purbalingga Hadi Iswanto, dan pihak swasta yaitu Hamdani Kosen, Librata Nababan, dan Adirawinata Nababan dalam sidang perkara korupsi pembangunan infrastruktur tersebut mengatakan jika uang korupsi tersebut digunakan untuk kegiatan PDI Perjuangan Purbalingga yang saat itu dipimpinnya.

Ketujuh, pengakuan Wa Ode Nurhayati, terpidana 5,5 tahun dalam kasus korupsi dana PPID (Percepatan Pembangunan Infrastruktur Daerah), pernah melapor ke KPK pada Senin, 17 September 2018. Ia menyatakan, kasus korupsi yang menjeratnya belum tuntas. Sebab, selain soal uang suap Rp 6 miliar yang menyeretnya pada 2012, Wa Ode menilai ada dana Rp120 miliar yang diterima partainya (PAN), tapi belum diusut.

\section{Regulasi yang Mendorong Partai Politik Bebas Korupsi dan Problematika Penerapannya}

Korupsi yang dilakukan parpol telah membuat pemerintah mengupayakan agar tercipta regulasi yang bisa membuat parpol lebih transparan dan terhindar dari praktik korup. Beberapa regulasi yang diidealkan untuk mendorong parpol bebas dari praktik korup itu diantaranya:

\section{1) Undang-Undang Partai Politik}

Parpol diatur dalam Undang-Undang Nomor 2 Tahun 2008 sebagaimana diubah dengan Undang-Undang Nomor 2 Tahun 2011 tentang tentang Partai Politik (UU Parpol). Dalam ketentuan undang-undang a quo terdapat beberapa pasal yang bermuara pada perwujudan parpol bebas korupsi, diantaranya tergambar pada tabel 1 berikut: 
Tabel 1. Jangkauan Pengaturan Keorganisasian Partai Politik Bebas Korupsi dalam Undang-Undang Partai Politik

\begin{tabular}{|c|c|c|c|}
\hline $\begin{array}{c}\text { Arah } \\
\text { Pengaturan } \\
\end{array}$ & Ketentuan & Dasar Hukum & Sasaran \\
\hline \multirow{3}{*}{$\begin{array}{l}\text { Kewajiban } \\
\text { yang } \\
\text { berorientasi } \\
\text { pencegahan } \\
\text { korupsi }\end{array}$} & $\begin{array}{l}\text { Kewajiban parpol membuat pembukuan } \\
\text { mengenai daftar penyumbang dan jumlah } \\
\text { sumbangan yang diterima, serta terbuka } \\
\text { kepada masyarakat }\end{array}$ & Pasal 13 huruf h & \multirow{3}{*}{$\begin{array}{l}\text { Ketentuan ini } \\
\text { berimplikasi } \\
\text { terhadap } \\
\text { keterbukaan } \\
\text { keuangan } \\
\text { parpol } \\
\text { sehingga } \\
\text { negara dapat } \\
\text { memeriksa } \\
\text { transparansi } \\
\text { keuangan dari } \\
\text { parpol } \\
\text { tersebut. }\end{array}$} \\
\hline & $\begin{array}{l}\text { Kewajiban parpol melaporan } \\
\text { pertanggungjawaban penerimaan dan } \\
\text { pengeluaran keuangan yang bersumber } \\
\text { dari dana bantuan APBN dan APBD }\end{array}$ & Pasal 13 huruf i & \\
\hline & $\begin{array}{l}\text { Kewajiban memiliki rekening khusus dana } \\
\text { kampanye pemilihan umum }\end{array}$ & Pasal 13 huruf $\mathrm{j}$ & \\
\hline \multirow{7}{*}{$\begin{array}{l}\text { Larangan } \\
\text { kepada } \\
\text { Partai } \\
\text { Politik } \\
\text { sebagai } \\
\text { Rambu } \\
\text { Identifikasi } \\
\text { Tindakan } \\
\text { Korupsi }\end{array}$} & $\begin{array}{l}\text { Jumlah sumbangan ke parpol tidak boleh } \\
\text { melebihi ketentuan yang ditetapkan } \\
\text { undang-undang }\end{array}$ & $\begin{array}{l}\text { Pasal } 35 \text { ayat (1) } \\
\text { huruf b dan huruf c jo } \\
\text { Pasal } 49\end{array}$ & \multirow{7}{*}{$\begin{array}{l}\text { Ketentuan ini } \\
\text { berimplikasi } \\
\text { terhadap } \\
\text { pembangunan } \\
\text { kredibilitas } \\
\text { Partai Politik } \\
\text { dan } \\
\text { terciptanya } \\
\text { kompetisi } \\
\text { Partai Politik } \\
\text { yang sehat }\end{array}$} \\
\hline & $\begin{array}{l}\text { Larangan menerima dari atau memberikan } \\
\text { kepada pihak asing sumbangan dalam } \\
\text { bentuk apa pun }\end{array}$ & $\begin{array}{c}\text { Pasal } 40 \text { ayat (3) } \\
\text { huruf a }\end{array}$ & \\
\hline & $\begin{array}{l}\text { Larangan menerima sumbangan berupa } \\
\text { uang, barang, ataupun jasa dari pihak mana } \\
\text { pun tanpa mencantumkan identitas yang }\end{array}$ & $\begin{array}{l}\text { Pasal } 40 \text { ayat ( } 3 \text { ) } \\
\text { huruf } b\end{array}$ & \\
\hline & jelas & & \\
\hline & $\begin{array}{l}\text { Larangan menerima sumbangan dari } \\
\text { perseorangan dan/atau perusahaan/badan } \\
\text { usaha melebihi batas yang ditetapkan }\end{array}$ & $\begin{array}{l}\text { Pasal } 40 \text { ayat (3) } \\
\text { huruf } \mathrm{c}\end{array}$ & \\
\hline & $\begin{array}{l}\text { Larangan meminta atau menerima dana } \\
\text { dari BUMN, BUMD dan BUMDes atau } \\
\text { dengan sebutan lainnya }\end{array}$ & $\begin{array}{l}\text { Pasal } 40 \text { ayat (3) } \\
\text { huruf } d\end{array}$ & \\
\hline & $\begin{array}{l}\text { Larangan menggunakan fraksi di MPR, DPR, } \\
\text { DPRD Provinsi dan Kab/Kota untuk sumber } \\
\text { pendanaan parpol }\end{array}$ & $\begin{array}{l}\text { Pasal } 40 \text { ayat ( } 3) \\
\text { huruf e }\end{array}$ & \\
\hline
\end{tabular}

Terlepas dari penjabaran di atas, undang-undang parpol menemui titik masalah pada implementasinya. Dimana undang-undang a quo menegaskan bahwa pengelolaan keuangan parpol dilakukan secara transparan dan akuntabel. Sehingga parpol wajib membuat laporan keuangan tahunan yang meliputi laporan realisasi anggaran, laporan neraca dan laporan kas. Laporan keuangan tersebut harus diaudit oleh akuntan publik dan diumumkan secara periodik. Tujuannya agar laporan keuangan bisa diakses publik, termasuk di dalamnya adalah daftar penyumbang. Namun ketentuan membuat laporan keuangan tahunan tersebut tidak diikuti oleh ketentuan teknis bagaimana membuat laporan keuangan tahunan. Implikasi dari problematika ini adalah sejak berlakunya UU No. 2 Tahun 2008 sesungguhnya tidak ada laporan keuangan parpol yang seragam, dan memenuhi standar pelaporan. Partai politik hanya menggugurkan kewajiban dengan membuat laporan keuangan asal-asalan, atau tidak membuat sama sekali karena keharusan membuat laporan keuangan tahunan ternyata tidak diikuti oleh ketentuan penjatuhan sanksi (Junaidi et.al, 2011: 77). Hal ini berbeda dengan ketentuan undang-undang yang mengharuskan parpol menyampaikan 
laporan pertanggungjawaban atas penggunaan subsidi negara kepada pemerintah. Laporan tersebut wajib disampaikan kepada masyarakat luas, jika tidak akan dikenakan sanksi berupa penundaan turunnya dana subsidi.
UU Pemilu dan UU Pilkada telah membuat beberapa langkah antisipasi agar parpol dalam penyelenggaraan pemilu terhindar dari praktek korup seperti beberapa ketentuan dalam tabel berikut:

\section{2) Undang-Undang Pemilu dan Undang- Undang Pilkada}

Tabel 2. Jangkauan Pengaturan Partai Politik Bebas Korupsi dalam Penyelenggaraan Pemilu

\begin{tabular}{l} 
Ketentuan \\
\hline Pasal 228 juncto Pasal 242 UU No. 7 Tahun 2017 tentang \\
Pemilu mengenai larangan parpol menerima imbalan dalam \\
bentuk apa pun pada proses pencalonan Presiden dan Wakil \\
Presiden, anggota DPR, DPRD provinsi, dan/atau DPRD \\
kabupaten/kota; dan ketentuan mengenai Partai Politik yang \\
terbukti menerima imbalan tersebut diberikan sanksi larangan \\
mengajukan calon pada periode berikutnya.
\end{tabular}

Pasal 47 UU No. 8 Tahun 2015 tentang Pilkada mengatur ketentuan mengenai Partai Politik atau gabungan Partai Politik yang dilarang menerima imbalan dalam bentuk apapun pada proses pencalonan Gubernur dan Wakil Gubernur, Bupati dan Wakil Bupati, serta Walikota dan Wakil Walikota; sanksi pemberian larangan Partai Politik atau gabungan Partai Politik yang bersangkutan untuk mengajukan calon pada periode berikutnya di daerah yang sama dan dikenakan denda sebesar 10 (sepuluh) kali lipat dari nilai imbalan yang diterima jika terbukti menerima imbalan yang dimaksud.

Pasal 76 ayat (1) UU Pilkada mengatur ketentuan mengenai larangan Partai Politik dan/atau gabungan Partai Politik yang mengusulkan pasangan calon dan pasangan calon perseorangan dilarang menerima sumbangan atau bantuan lain untuk kampanye yang berasal dari:

a. negara asing, lembaga swasta asing, lembaga swadaya masyarakat asing dan warga negara asing;

b. penyumbang atau pemberi bantuan yang tidak jelas identitasnya;

c. Pemerintah dan Pemerintah Daerah; dan

d. badan usaha milik negara, badan usaha milik desa atau sebutan lain.

Adapun sanksi atas pelanggaran ketentuan tersebut tercantum pada Pasal 76 ayat (3) dimana Partai Politik dan/atau gabungan Partai Politik yang mengusulkan pasangan calon yang melanggar akan dikenai sanksi berupa pembatalan pasangan calon yang diusulkan. a. berorientasi pada persoalan pemilu yang masih terciderai dengan politik transaksional negatif seperti politik uang yang marak.

b. berepisentrum pada transparansi keuangan parpol dalam proses pemilihan umum dan pemilihan kepala daerah baik saat persiapan maupun saat pelaksanaan. 
Hal yang perlu diperhatikan adalah terjadinya problematika terhadap penerapan regulasi tersebut. Berdasarkan kajian yang telah dilakukan Indonesian Corruption Watch (ICW), tulisan Fariz dan Ilyas dalam Perdana et.al (2018: 25) 10) menyatakan bahwa terdapat beberapa kelemahan mendasar dari regulasi pendanaan parpol, diantaranya adanya ketentuan mengenai peningkatan batasan sumbangan dana kampanye dari para donatur ternyata tidak diiringi dengan perbaikan sistem audit dana kampanye yang lebih akuntabel. Sedangkan pada tataran praktek, problematika yang terjadi adalah manipulasi dana kampanye pemilu. Manipulasi yang dimaksud yaitu (https://nasional.kompas.com/read/2019/ 05/02/09515391/auditor-diminta-

cermati -titik-kerawanan-manipulasi-dana kampanye), pertama, parpol mencatat pemasukan dari sumbangan yang dilarang dengan menggunakan penyumbang fiktif demi menyamarkan dana dari donatur ilegal. Kedua, parpol tidak melakukan pencatatan mengenai pemasukan dari sumbangan-sumbangan terlarang dan tidak memasukan ke dalam rekening khusus dana kampanye yang diatur dalam regulasi sehingga secara eksplisit tidak nampak adanya penerimaan dari sumbersumber ilegal. Ketiga, parpol memasukan sumbangan terlarang ke dalam rekening parpol yang kemudian dimasukkan ke dalam rekening khusus dana kampanye. Ketentuan dalam undang-undang pemilu yang tidak memuat batasan maksimal jumlah sumbangan yang bersumber dari parpol dijadikan celah oleh parpol yang bersangkutan. Keempat, parpol mencatat penerimaan tidak dalam jumlah sebenarnya. Hal inilah yang kemudian menjadikan regulasi saat ini yang samar dalam perwujudan parpol yang berintegritas dan bebas korupsi.

Jika dibandingkan dengan penerapan pelaporan dana kampanye di berbagai negara, terjadi perbedaan dalam menentukan frekuensi pelaporannya. Negara Bagian Colorado (USA), misalnya, mewajibkan kandidat menyampaikan laporan keuangan setiap triwulan (pada tanggal 15 Januari, 15 April, 15 Juli, dan 15 Oktober). Selain itu, kandidat juga wajib menyampaikan laporan bulanan sejak enam bulan sebelum pemilihan serta satu laporan dua minggu sebelum dan sesudah pemilihan. Pada perkembangan terakhir, pelaporan tidak hanya dalam bentuk tertulis, tetapi juga melalui perangkat teknologi informasi yang dapat diakses secara mudah oleh publik. Pelaporan seperti ini dimaksudkan agar para pemilih dapat membuat keputusan mengenai partai/calon yang akan dipilih berdasarkan sumber penerimaan dana kampanye (Surbakti, 2011: 73).

\section{3) Pakta Integritas dalam Peraturan Komisi Pemilihan Umum}

Upaya penegasan pentingnya etika peserta pemilu, Komisi Pemilihan Umum (KPU) telah mengeluarkan Peraturan KPU Nomor 20 Tahun 2018 tentang Pencalonan anggota legislatif. PKPU ini memuat pakta integritas, yang salah satu isinya sebagaimana diatur dalam Pasal 6 ayat (1) adalah adanya kesepakatan dari pimpinan Parpol untuk tidak menyertakan atau mencalonkan seorang Caleg yang berasal dari mantan terpidana korupsi.

Dimana aktualisasi pertama telah dilakukan dengan penandatanganannya oleh parpol peserta Pemilu 2019 yang menyepakati komitmen Sistem Integritas Partai Politik (SIPP) (https:// nasional.kompas.com/ $\mathrm{read} / 2018 / 12 / 04 / 16571931 /$ parpolpeserta-pemilu-2019-sepakati-sistemintegritas-partai-politik?page=all).

Penandatanganan kesepakatan tersebut dilakukan oleh para pimpinan parpol didampingi pimpinan KPK dengan berkoordinasi bersama KPU, Bawaslu, dan 
Kemendagri. Melalui pakta ini disimbolkan sebagai pengikat etika moral parpol dalam penyelenggaraan pesta demokrasi yang berkualitas dan komitmen memerangi korupsi.

Dari sini terlihat bahwa pakta integritas adalah aspek etik yang diformalkan melalui regulasi yang harus dipatuhi, bukan lagi sekedar kesepakatan. Sehingga pakta integritas ini bisa dikatakan sebagai langkah preventif agar tidak terjadi kejahatan korupsi berulang oleh mereka yang pernah dijatuhi hukuman tindak pidana korupsi.

\section{Konsep dan Desain Ideal Penegakan Hukum Korupsi Partai Politik untuk Menciptakan Partai Politik yang Bebas Korupsi}

\section{A. Prasyarat Utama: Penegasan Partai Politik sebagai Korporasi}

Sebelum membahas desain yang tepat untuk menindak parpol yang terlibat praktik korup, perlu dijabarkan terlebih dahulu mengenai penafsiran parpol sebagai korporasi baik dari sisi regulasi maupun teori. Hal ini penting karena akan menjadi pondasi dalam desain penegakan hukum yang akan di bangun yang kemudian mengantarkan pada keseragaman pemahaman bahwa parpol dapat dipidana dengan statusnya sebagai korporasi.

Jika ditilik bangunan Pasal 1, Pasal 2, dan Pasal 3 UU Parpol, maka parpol dikategorikan sebagai badan hukum yang didirikan oleh sekelompok orang (WNI). Dari konstruksi tersebut yang kemudian dikaitkan dengan bunyi Pasal 1 angka 1 UU No. 31 Tahun 1999 juncto UU No. 20 Tahun 2001 tentang Pemberantasan Tindak Pidana Korupsi (UU Tipikor) dimana "Korporasi adalah kumpulan orang dan/atau kekayaan yang terorganisasi baik merupakan badan hukum maupun bukan badan hukum" dan Pasal 1 angka 3 undang-undang a quo dimana "Setiap orang adalah orang perseorangan atau termasuk korporasi", maka melalui pendekatan regulasi ini parpol dapat dimasukkan dalam jenis setiap orang yang dibebani pertanggungjawaban hukum jika melakukan tindak pidana korupsi. Pada tataran inilah kemudian, parpol dapat dimasukkan sebagai korporasi berbadan hukum yang dapat menjadi subjek hukum pidana, sehingga parpol sebagai korporasi berbadan hukum dapat diperiksa apabila diduga melakukan tindak pidana korupsi.

Adapun jika vis a vis dilihat pada Pasal 20 undang-undang a quo diatur sebagai berikut:

(1) Dalam hal tindak pidana korupsi dilakukan oleh atau atas nama suatu korporasi, maka tuntutan dan penjatuhan pidana dapat dilakukan terhadap korporasi dan atau pengurusnya.

(2) Tindak pidana korupsi dilakukan oleh korporasi apabila tindak pidana tersebut dilakukan oleh orang-orang baik berdasarkan hubungan kerja maupun berdasarkan hubungan lain, bertindak dalam lingkungan korporasi tersebut baik sendiri maupun bersama-sama.

Perihal mekanisme penegakan pertanggungjawaban korporasi ini, Mahkamah Agung juga telah menetapkan Peraturan Mahkamah Agung Nomor 13 Tahun 2016 tentang Tata Cara Penanganan Perkara Tindak Pidana oleh Korporasi. Adanya ketentuan dalam Perma tersebut merupakan langkah konkrit dalam penegakan hukum yang dapat diberlakukan terhadap parpol "jika dan hanya jika" disepakati bahwa parpol masuk dalam kategori korporasi. Sebagaimana rumusan Pasal 4 yang berbunyi:

(1) Korporasi dapat dimintakan pertanggungjawaban pidana sesuai dengan ketentuan pidana korporasi 
dalam undang-undang yang mengatur tentang korporasi.

(2) Dalam menjatuhkan pidana terhadap korporasi, hakim dapat menilai kesalahan korporasi sebagaimana ayat

(1) antara lain:

a. Korporasi dapat memperoleh keuntungan atau manfaat dari tindak pidana korupsi tersebut atau tindak pidana tersebut dilakukan untuk kepentingan korporasi;

b. Korporasi membiarkan terjadinya tindak pidana atau;

c. Korporasi tidak melakukan langkahlangkah yang diperlukan untuk melakukan pencegahan, mencegah dampak yang lebih besar dan memastikan kepatuhan terhadap ketentuan hukum yang berlaku guna menghindari terjadinya tindak pidana.

Penulis tentunya menyadari bahwa persepsi mengenai parpol masuk dalam koridor korporasi mengandung perdebatan secara konseptual khususnya di Indonesia. Adapun saat ini pendikotomian antara parpol dan korporasi dapat terlihat pada tabel berikut:

Tabel 3. Matrik Perbandingan Korporasi dan Partai Politik

\begin{tabular}{|c|c|c|}
\hline Unsur-unsur & $\begin{array}{c}\text { Korporasi } \\
\text { (UU 40/2007) }\end{array}$ & $\begin{array}{c}\text { Partai Politik } \\
\text { (UU 2/2008 jo } \\
\text { UU 2/2011) }\end{array}$ \\
\hline \multirow{2}{*}{ Pendirian } & $\begin{array}{l}\text { Didirikan } \\
\text { berdasarkan } \\
\text { kesepakatan }\end{array}$ & $\begin{array}{c}\text { Didirikan } \\
\text { berdasarkan } \\
\text { kesepakatan }\end{array}$ \\
\hline & $\begin{array}{l}\text { oleh } 2 \text { (dua) } \\
\text { orang atau } \\
\text { lebih }\end{array}$ & $\begin{array}{l}\text { paling sedikit } \\
50 \text { (lima puluh) } \\
\text { orang WNI }\end{array}$ \\
\hline Organ & $\begin{array}{l}\text { Rapat Umum } \\
\text { Pemegang } \\
\text { Saham, Direksi, } \\
\text { dan Dewan } \\
\text { Komisaris }\end{array}$ & $\begin{array}{l}\text { AD/ART dan } \\
\text { Pengurus }\end{array}$ \\
\hline Legalitas & $\begin{array}{c}\text { Berbentuk } \\
\text { badan hukum }\end{array}$ & $\begin{array}{c}\text { Berbentuk } \\
\text { badan hukum }\end{array}$ \\
\hline
\end{tabular}

\begin{tabular}{ccc}
\hline Tujuan & $\begin{array}{c}\text { Didaftarkan } \\
\text { kepada } \\
\text { Kemenkumham }\end{array}$ & $\begin{array}{c}\text { Didaftarkan } \\
\text { kepada } \\
\text { Kemenkumham } \\
\text { vote-seking } \\
\text { Pffice-seeking } \\
\text { policy-seeking }\end{array}$ \\
\hline $\begin{array}{c}\text { Orientasi } \\
\text { Kegiatan }\end{array}$ & ekonomi & Politik \\
\hline $\begin{array}{c}\text { Sumber } \\
\text { Keuangan }\end{array}$ & $\begin{array}{c}\text { Persekutuan } \\
\text { modal }\end{array}$ & $\begin{array}{c}\text { Iuran anggota, } \\
\text { sumbangan } \\
\text { sah, bantuan } \\
\text { APBN/APBD. }\end{array}$ \\
\hline $\begin{array}{c}\text { Pertanggung- } \\
\text { jawaban } \\
\text { pidana }\end{array}$ & $\begin{array}{c}\text { Individu } \\
\text { dan/atau } \\
\text { kelembagaan }\end{array}$ & Individu \\
\hline \multicolumn{3}{c}{} \\
\hline
\end{tabular}

Berdasarkan tabel di atas memang terlihat bahwa korporasi memiliki corak berbeda dengan parpol jika korporasi dimaknai berdasar pada Undang-Undang No. 40 Tahun 2007 tentang Perseoran Terbatas. Terutama pada hal tujuan, orientasi kegiatan, sumber keuangan, dan pertanggungjawaban. Namun demikian, jika kembali pada unsur korporasi dalam UU Tipikor yang terdiri atas unsur kumpulan orang dan/atau kekayaan yang terorganisasi serta unsur badan hukum maupun bukan badan hukum, tentunya akan membawa implikasi yang berbeda. Terlebih, tafsir korporasi yang hanya berorientasi pada konteks ekonomi atau profit sebetulnya merupakan tafsir sempit. Dinamika perkembangan hukum saat ini, mau tidak mau menuntut adanya tafsir yang lebih luas dan progresif demi terwujudnya keadilan substansial, termasuk pada konteks perluasan tafsir korporasi kepada parpol dalam tindak pidana korupsi. Sebagai contoh yaitu perbandingan antara konsep pemidanaan parpol sebagai korporasi pada sistem hukum pidana Amerika Serikat dan Belanda.

Dalam memutuskan perkara pidana yang melibatkan korporasi, Amerika Serikat justru cenderung mengakomodir pengertian korporasi yang sangat luas. Kasus pertama kali yang melibatkan 
keberadaan korporasi adalah kasus the New York Central \& Hudson River Railroad Co. melawan United States (USSC: 2016: 493-494), yang di dalamnya pengertian korporasi dipahami sangat luas, yakni " $a$ person other than individual" atau seorang selain dari pada individu dapat diklasifikasi sebagai korporasi apapun dan bagaimanapun bentuknya. Lebih jelasnya, korporasi (Lodder: 2017, 55) dirumuskan dengan sebuah nomenklatur bernama "organisasi" yang tidak lagi hanya terbatas orientasi pada aspek ekonomi/pendapatan, melainkan lebih luas lagi, misalnya pemerintahan dan subdivisi politik (governments and political subdivisions), serta organisasi non-profit.

Hal senada ditemukan pula pada Belanda. Adapun subjek delik badan hukum atau legal person yang diatur Belanda cenderung memiliki makna yang sangat luas. Cakupan subjek delik yang ditentukan oleh Belanda lebih luas dan bahkan diatur secara detail, baik badan hukum publik maupun badan hukum privat yang mana keseluruhannya dapat dikenakan pertanggungjawaban pidana dalam sistem hukum Belanda. Bahkan, beberapa badan publik telah diputus bersalah atas beberapa perbuatan pidana yang menandakan bahwa Belanda memang sangat luas dalam mengatur mengenai subjek tindak pidana. Dalam hal ini tentunya parpol mendapat fokus yang sama akan sistem pemidanaan legal person ini termasuk jika dikaitkan dengan parpol sebagai salah satu badan hukum publik (Soleh: 2018: 312).

Kemudian dari sisi teori, bahwa korporasi dapat melakukan tindak pidana dengan melihat apakah tindak pidana yang dilakukan oleh pengurus atau anggota dari korporasi tersebut masih dalam ruang lingkup kewenangan dalam korporasi ataukah merupakan kehendak pribadi. Secara lebih lengkap korporasi dinilai telah melakukan tindak pidana dapat dilihat keterkaitannya kepada beberapa teori (Ali, 2016: 46-47), yaitu pertama, teori pelaku fungsional (functioneel daaderschap). Korporasi tidak perlu selalu melakukan perbuatan secara fisik, tetapi dapat saja perbuatan pidana dilakukan oleh pegawainya asal saja perbuatan tersebut masih dalam ruang lingkup fungsi dan kewenangan korporasi sesuai dengan ketentuan-ketentuan yang tercantum dalam AD/ART.

Kedua, teori identifikasi. Korporasi dapat melakukan pidana secara langsung melalui orang-orang yang berhubungan erat dengan korporasi dan dipandang sebagai korporasi itu sendiri. Perbuatan yang dilakukan oleh anggota korporasi dianggap sebagai perbuatan korporasi selama perbuatan tersebut berkaitan dengan korporasi.

Ketiga, vicarious liability. Doktrin ini berasal dari employment principle bahwa majikan adalah penanggung jawab utama dari perbuatan para buruh/karyawan. Keempat, strict liability. Pertanggungjawaban korporasi dapat juga sematamata berdasarkan undang-undang, yaitu dalam hal korporasi melanggar atau tidak memenuhi kewajiban/kondisi/situasi tertentu yang ditentukan oleh undangundang.

Berdasarkan logika yang ada tersebut, baik dari sisi regulasi, perbandingan, maupun teori, maka bisa didapat titik temu dalam menjerat parpol, yakni dengan menyebutnya sebagai badan hukum layaknya korporasi, dengan begitu parpol dapat dijadikan subjek hukum pidana apabila terlibat dalam tindak pidana korupsi. Pada tataran inilah kiranya penulis mengambil sikap bahwa parpol masuk dalam kategori korporasi sehingga padanya bisa dimintai pertanggungjawaban pidana jika terlibat dalam praktik korup. Meski mungkin ada bantahan lain, paling tidak, konstruksi 
berpikir seperti ini dapat menjadi jalan keluar dari segala kebuntuan dan pilihan berat untuk menghukum parpol atas keterlibatannya dalam tindak pidana korupsi.

Memang dalam praktik terdapat problem berupa ketidakseragaman pemahaman bahwa parpol dapat diperlakukan sebagai korporasi, sehingga diperlukan pengaturan yang tegas dan eksplisit bahwa parpol adalah badan hukum/korporasi. Padahal, dalam ajaran ilmu hukum, subjek hukum adalah orang dan badan hukum. Melepas tanggungjawab parpol atas tindak pidana korupsi yang melibatkannya jelas bertentangan dengan dogma dan ajaran hukum. Pada akhirnya tentu perlu upaya memperluas subjek korporasi dalam UU Tipikor. Tentunya hal ini dapat didorong pada praktek penegakan hukumnya (law enforcement). Jaksa dan hakim harus berani memberikan tafsir luas dan progresif terhadap korporasi dalam menyikapi problematika korupsi parpol saat ini. Hakim dalam membentuk hukum bukan hanya berorientasi pada legisme semata, namun juga hakim dituntut melakukan penemuan hukum melalui metode kontruksi hukum atau yang lebih dikenal dengan freirerchhtschule, yang dimana hakim diberi kebebasan dalam menemukan hukum, dalam arti, hakim bukan sekedar menerapkan undangundang, akan tetapi juga memperluas dan membentuk hukum melalui putusanya. Dalam aliran ini, hakim dituntut untuk menyeimbangkan antara keadilan dan kemanfaatan (Asyhadie: 2014: 178).

\section{B. Desain Penegakan Hukum Korupsi Partai Politik}

Beranjak dari pembahasan parpol adalah korporasi sebagai pondasi dasar penegakan, terdapat 3 tipe tindak pidana korupsi yang dapat dijadikan parameter dalam desain yang akan dirumuskan, yaitu

(Mulyadi, 2008: 186):

1. Tindak Pidana Korupsi Tipe Pertama, terdapat dalam Pasal 2 UU Tipikor yang menyebutkan bahwa: "Setiap orang yang secara melawan hukum melakukan perbuatan memperkaya diri sendiri atau orang lain atau suatu korporasi yang dapat merugikan keuangan negara atau perekonomian negara, dipidana dengan pidana penjara seumur hidup atau pidana penjara paling singkat 4 (empat) tahun paling lama 20 (dua puluh) tahun, dan denda paling sedikit dua ratus juta rupiah dan paling banyak satu milyar rupiah." Dalam hal tindak pidana korupsi sebagaimana dimaksud dalam ayat (1) dilakukan dalam keadaan tertentu pidana mati dapat dijatuhkan.

2. Tindak Pidana Korupsi Tipe Kedua, diatur dalam ketentuan pasal 3 UU Tipikor yang menyebutkan bahwa: "Setiap orang yang dengan tujuan menguntungkan diri sendiri atau orang lain atau suatu korporasi, menyalahgunakan kewenangan, kesempatan atau sarana yang ada padanya karena jabatan atau kedudukan yang dapat merugikan keuangan negara atau perekonomian negara, dipidana dengan pidana seumur hidup, atau pidana penjara paling singkat 1 (satu) tahun dan paling lama 20 (dua puluh) tahun dan atau denda paling sedikit lima puluh juta rupiah dan paling banyak satu milyar rupiah.

3. Tindak Pidana Korupsi Tipe Ketiga, terdapat dalam ketentuan Pasal 5, 6, 8, $9,10,11,12,12 \mathrm{~A}, 12 \mathrm{~B}, 12 \mathrm{C}$ dan $13 \mathrm{UU}$ Tipikor, berasal dari pasal-pasal KUHP yang kemudian sedikit dilakukan modifikasi perumusan ketika ditarik menjadi tindak pidana korupsi sesuai Undang-Undang Nomor 20 Tahun 2001 dengan menghilangkan redaksional 
kata "sebagaimana dimaksud dalam pasal-pasal....KUHP" seperti formulasi dalam ketentuan UU Tipikor. Apabila dikelompokkan, korupsi tipe ketiga dapat dibagi menjadi 4, yaitu:

a. Penarikan perbuatan yang bersifat penyuapan, yakni pasal 209, 210, 418, 419, dan Pasal 420 KUHP.

b. Penarikan perbuatan yang bersifat penggelapan, yakni pasal 415, 416, dan pasal 417 KUHP. c. Penarikan perbuatan yang bersifat kerakusan (knevelarij, extortion), yakni pasal 423, dan 425 KUHP.

d. Penarikan perbuatan yang berkolerasi dengan pemborongan, leverensir dan rekanan, yakni pasal 387, 388, dan 435 KUHP.

Adapun desain penegakan hukum tindak pidana korupsi parpol tergambar pada bagan di bawah ini:

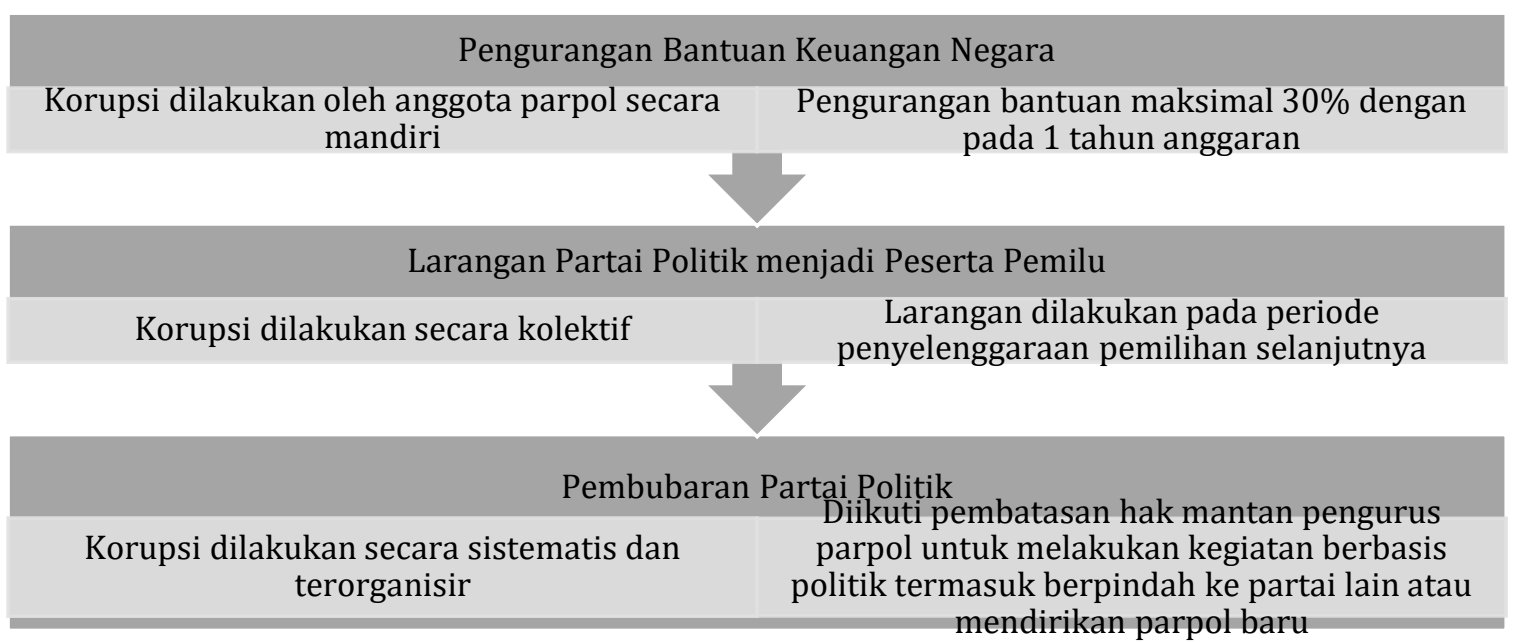

Bagan 1. Desain Penegakan Korupsi Partai Politik

Keseluruhan bangunan kerangka tersebut didasari pada tindak pidana korupsi tipe pertama, kedua, dan/atau ketiga. Selain daripada itu perlu digarisbawahi pula bahwa kontruksi desain yang diinginkan adalah parpol dapat dijerat seperti halnya korupsi korporasi, sehingga sanksi pidana dapat dikenakan baik pada pengurus maupun parpol secara kelembagaan.

Sehubungan dengan konsep kejahatan korporasi, terdapat beberapa pihak yang dapat dimintakan pertanggungjawaban pidananya terkait dengan kejahatan korporasi, yakni korporasi itu sendiri, pengurus korporasi dan karyawan/pekerja korporasi.

Berdasarkan hal tersebut maka sanksi terhadap parpol nantinya dimuarakan sebagai pidana tambahan yang harus diberikan sepanjang dapat dibuktikan melalui putusan pengadilan yang berkekuatan hukum tetap bahwa uang hasil korupsi nyata mengalir ke parpol bersangkutan dan adanya keterlibatan parpol baik langsung maupun tidak langsung dalam korupsi yang terjadi.

Sebagaimana bagan di atas, konstruksi pertama yang digagas adalah pengurangan bantuan keuangan negara terhadap parpol. Hal yang perlu diidentifikasi adalah korupsi tersebut dilakukan secara sendiri oleh anggota atau pengurus parpol yang sedang menduduki jabatan publik dan uang itu terbukti dialirkan ke parpol. Pada tataran ini, selain oknum tersebut dikenai pidana sesuai aturan perundang-undangan, pidana tambahan juga dikenakan pada parpol sebagai tanggungjawab moral parpol terhadap publik atas kegagalan pendidikan politik terhadap kadernya, 
salah satunya melalui pemotongan subsidi bantuan pendanaan parpol dari negara.

Sebagaimana diketahui, secara empiris parpol melaksanakan tugas yang bersifat publik. Tugas publik tersebut setidak-tidaknya mempersiapkan dan mengajukan calon anggota DPR dan DPRD; calon presiden dan wakil presiden; dan calon kepala daerah. Sebagai upaya untuk menjamin persaingan yang adil antarparpol peserta pemilihan atau antar-calon, sangat wajar pula apabila negara melalui APBN menyediakan public funding, baik yang dialokasikan secara langsung maupun tidak langsung, baik yang diberikan sebagai insentif bagi partai untuk menjalankan fungsinya maupun sebagai upaya menjamin modal dasar minimal yang sama antar-partai (Surbakti, 2011: 19). Saat ini, anggaran bantuan keuangan parpol telah terjadi penambahan 10 kali lipat berdasarkan Peraturan Pemerintah Nomor 1 Tahun 2018 tentang Perubahan Kedua atas Peraturan Pemerintah Nomor 5 Tahun 2009 tentang Bantuan Keuangan Kepada Partai Politik dimana sebelumnya dana bantuan keuangan kepada parpol tingkat pusat yang mendapatkan kursi di DPR Rp 108, kini menjadi Rp 1.000 setiap suara sah. Kemudian untuk tingkat DPRD provinsi menjadi Rp 1.200 per suara sah dan tingkat DPRD kota/kabupaten menjadi Rp 1.500 per suara sah. Bantuan dana parpol yang diberikan oleh negara tersebut diprioritaskan untuk melaksanakan pendidikan politik bagi anggota parpol dan masyarakat serta sebagai biaya operasional sekretariat parpol. Dengan kenaikan tersebut berbanding lurus dengan peningkatan dana bantuan parpol dari sebelumnya 13,5 miliar dalam setahun menjadi 111 miliar untuk setiap tahunnya (https://mediaindonesia.com/read/detail/ 274450-kemendagri-berupaya-tambahbantuan-dana-parpol).
Adapun diskursus mengenai subsidi negara untuk parpol yang perlu dinaikkan sebagai upaya mengurangi korupsi pendanaan di parpol memang dirasa relevan. Hal ini dimaksudkan untuk semakin menutup celah korupsi yang selama ini marak dilakukan oknum elite partai, baik di lembaga legislatif maupun eksekutif. Sebagaimana kasus-kasus korupsi yang ada dimana ada dugaan aliran dana ke partai untuk membiayai. Apabila merujuk pada perkembangan di dunia, banyak negara yang juga mengembangkan model subsidi negara terhadap parpol. Misalnya Inggris, Italia dan Australia yang subsidi negara lebih kecil dibandingkan sumbangan. Sementara itu Perancis, Denmark dan Jepang subsidi negara sama dengan sumbangan. Austria, Swedia dan Meksiko bantuan negara lebih besar dari sumbangan. Sementara itu Uzbekistan $100 \%$ pendanaan parpol berasal dari subsidi negara (Susanto, 2017: 233). Walapun memang terdapat realitas pula bahwa subsidi negara yang besar belum tentu berbanding lurus dengan terbebasnya parpol dari korupsi. Negara yang bisa dijadikan contoh yaitu Meksiko, sebagai salah satu negara yang relatif besar dalam memberikan dana sumbangan kepada parpol $(70 \%$ dari kebutuhan parpol). Namun kenyataannya korupsi masih terus merajalela di negara tersebut. Transparency

International dalam laporannya soal indeks persepsi korupsi global 2016 mencatat Meksiko berada di peringkat ke123 dari 176 negara (https://tirto.id/bercermin-dari-negaralain-soal-dana-parpol-cvw7). Begitu juga di Spanyol, konsekuensi subsidi parpol ternyata memiliki dampak kartelisasi partai. Partai politik menjadi oportunis dan permisif. Akibatnya, partai lebih tertutup dan tidak memiliki rasa tanggung jawab terhadap publik. Parpol lebih 
tunduk kepada kekuasaan ketimbang kepada rakyat karena dianggap sebagai pemenuhan finansial partai (https://news.detik.com/kolom/d3631084/dana-subsidi-dan-akuntabilitasparpol).

Terlepas dari diskursus tersebut, adalah hal wajar dan relevan pula ketika terdapat desain penegakan hukum korupsi parpol dimana tingkatan pertama dengan mengurangi subsidi negara kepada partai. Sehingga, ketika parpol dikenakan pidana tambahan berupa pemotongan dana bantuan parpol tersebut, diharapkan muncul adanya kesadaran untuk menempatkan kader-kader terbaiknya dalam menduduki jabatan publik agar terhindar dari perilaku korup.

Adapun prosentase maksimal pemotongan 30 persen dianggap sebagai angka yang proporsional yang didasarkan pada sejauh mana tindakan korupsi dan dampak dari tindakan tersebut. Besaran final yang dikenakan pemotongan tentunya bergantung pada putusan pengadilan.

Undang-Undang Nomor 2 Tahun 2008 tentang Partai Politik sebenarnya juga telah mengatur mekanisme pemberian sanksi administratif berupa penundaan bantuan dana parpol dari negara ketika terjadi pengabaian kewajiban parpol untuk menyampaikan laporan pertanggung-jawaban secara berkala 1 (satu) tahun sekali terhadap penerimaan dan pengeluaran keuangan yang bersumber dari dana bantuan APBN dan APBD. Ketentuan ini berimplikasi terhadap tertibnya administrasi parpol dalam pelaporan keuangan sebagaimana yang diatur di Pasal 13 huruf i undangundang a quo. Sehingga pada tataran inilah kemudian dirasa tepat ketika juga diterapkan sanksi yang hampir serupa yaitu pemotongan bantuan dana parpol sebagai pidana tambahan dalam upaya meminimalkan perilaku korupsi di tubuh parpol.

Konstruksi kedua, diberikan larangan untuk menjadi peserta pemilu pada periode berikutnya. Hal yang perlu diidentifikasi terkait ini adalah korupsi tersebut dilakukan secara kolektif oleh anggota atau pengurus parpol dan uangnya dialirkan ke parpol. Dari data yang diperoleh tahun 2018 bahwa sedikitnya 545 atau $61 \%$ dari aktor korupsi yang dijerat Komisi Pemberantasan Korupsi (KPK) adalah anggota DPR, DPRD provinsi, kabupaten, dan kota, serta para kepala daerah yang diusung parpol

(https://www.beritasatu.com/yudodahono/nasional/524403/sistem-politikmembuka-ruang-korupsi), yang sebagian besar secara tidak langsung dilakukan kolektif. Hal ini terbukti misalnya dalam kasus anggota DPRD Kota Malang pada tahun 2018 dalam dugaan tindak pidana suap pembahasan APBD-P Pemkot Malang, dimana sebanyak 41 orang anggota DPRD Kota Malang yang terlibat korupsi ditangkap KPK. Selain itu terdapat pula kasus korupsi di lingkungan DPRD Jambi tahun 2019 yang menyeret 12 orang anggota DPRD Jambi. Adapun di awal tahun 2020, sebanyak 14 orang anggota DPRD Sumatera Utara ditetapkan oleh KPK sebagai tersangka kasus dugaan tindak pidana suap di era Gubernur Gatot Pujo Nugroho (https://www.bbc.com/indonesia/indonesi a-45464288). Pada desain tingkat kedua ini, selain pemberian sanksi pidana, sanksi tambahan juga diberikan kepada parpol dengan tidak diperbolehkannya menjadi peserta pemilu periode selanjutnya, baik di tingkat pemilu Presiden, DPR, DPRD Provinsi, DPRD Kabupaten/Kota ataupun pemilihan kepala daerah.

Sejauh ini sebenarnya di dalam undang-undang terkait pemilu dan pilkada telah mengatur ketentuan mengenai 
sanksi larangan partai untuk mengajukan calon pada pemilihan periode berikutnya ketika memenuhi unsur yang dilarang dalam kedua undang-undang tersebut. Unsur yang dimaksud yaitu parpol menerima imbalan dalam proses pencalonan dan terbukti melalui putusan pengadilan yang telah memperoleh kekuatan hukum tetap. Namun, ketentuan tersebut terbatas kasus dana sumbangan pencalonan, tidak meluas pada tataran tindak pidana korupsi. Dalam pejatuhan sanksi pun bukan larangan menyeluruh. Dengan demikian, desain kedua ini, parpol secara menyeluruh pada tingkatan pemilihan apapun dilarang mendaftarkan diri menjadi peserta pemilihan periode berikutnya jika saat anggota atau pengurus parpol saat berkuasa terbukti secara kolektif melakukan tindak pidana korupsi. Tentunya hal ini diorientasikan pada pembenahan internal parpol dan efek jera fundamental bagi semua pihak.

Konstruksi ketiga, dilakukan pembubaran parpol diikuti dengan larangan bagi pengurus parpol untuk melakukan kegiatan politik termasuk berpindah ke partai lain atau mendirikan parpol baru. Hal ini dapat dikonstruksikan bahwa larangan ini berlaku sepuluh sampai lima belas tahun bagi parpol yang dibubarkan akibat korupsi. Terkait ini yang perlu diidentifikasi adalah adanya korupsi yang dilakukan secara sistematis dan terorganisir oleh parpol dan terdapat dana korupsi yang mengalir ke parpol. Artinya, terdapat perintah yang terstruktur dari pengurus atau melibatkan pengurus untuk melakukan korupsi. Selain itu, untuk desain ini juga diberlakukan terhadap tindak pidana korupsi yang dilakukan berulang, maka terhadap parpol yang melakukan tindakan tersebut bisa ditindak dengan pembubaran berdasarkan putusan pengadilan yang berkekuatan hukum tetap.
Selama ini, syarat pembubaran parpol sebagaimana diatur dalam UU Parpol masih berkutat pada dua syarat utama. Pertama, terhadap partai yang telah dibekukan oleh pengadilan negeri selama satu tahun akibat melakukan kegiatan yang bertentangan dengan UUD 1945 dan peraturan perundang-undangan atau melakukan kegiatan yang membahayakan keutuhan dan keselamatan NKRI tetapi dalam masa pembekuan atau pasca pembekuan masih melakukan kegiatan serupa, maka terhadapnya dapat dilakukan pembubaran. Kedua, apabila parpol terbukti menganut dan mengembangkan serta menyebarkan ajaran atau paham komunisme/MarxismeLeninisme maka langsung dibubarkan tanpa pembekuan terlebih dahulu. Terhadap pelanggaran yang dilakukan atas dua syarat tersebut, pembubaran parpol dilakukan melalui mekanisme peradilan di Mahkamah Konstitusi.

Dari beberapa syarat pembubaran parpol yang dikemukakan di atas, dalam konstruksi yang ketiga ini, syarat "larangan melakukan kegiatan yang bertentangan dengan peraturan perundang-undangan" bisa dijadikan pintu masuk untuk menghukum parpol yang melakukan tindak pidana korupsi. Jadi pelanggaran terhadap undang-undang ke depan tindak hanya dibatasi pada pelanggaran UU Parpol, melainkan termasuk juga undang-undang lain dalam hal ini adalah UU Tipikor. Sehingga, sebagaimana argumentasi yang menyatakan bahwa parpol bisa disamakan dengan badan hukum seperti halnya korporasi, maka hukuman kepada parpol yang melakukan tindak pidana korupsi juga bisa diberikan termasuk pada badan hukumnya. Dengan konstruksi demikian, pelanggaran terhadap UU Tipikor yang dilakukan oleh parpol bisa menjadi syarat permohonan untuk melakukan pembubaran terhadap parpol. 
Terkait dengan pembubaran parpol ini terdapat tiga skenario yang ditawarkan:

1. Partai politik yang terbukti melakukan tindak pidana korupsi di pengadilan Tipikor, digugat pembekuannya oleh pemerintah ke pengadilan negeri. Dalam hal ini bisa diwakili oleh Jaksa Agung dan/atau Menteri yang ditugasi oleh Presiden untuk itu. Jika dikabulkan dan tidak dilakukan upaya hukum kasasi ke Mahkamah Agung, maka pemerintah dapat menggunakan putusan pengadilan tersebut untuk mengajukan permohonan pembubaran parpol ke Mahkamah Konstitusi;

2. Partai politik yang melakukan korupsi dan digugat pembekuan oleh pemerintah, tetapi menang kasasi, tetap dimohonkan pembubarannya ke Mahkamah Konstitusi; dan

3. Partai politik yang terbukti melakukan korupsi langsung dimohonkan pembubarannya ke Mahkamah Konstitusi oleh pemerintah tanpa didahului pembekuan.

Setelah parpol dibubarkan melalui mekanisme itu, sebagai bentuk hukuman tambahan dan untuk mencegah terulangnya tindakan korup yang dilakukan pengerus partai yang sudah dibubarkan tersebut, maka terhadap pengurus ini diberikan larangan untuk melakukan kegiatan politik termasuk berpindah ke partai lain atau mendirikan parpol baru. Bisa dikonstruksikan bahwa larangan ini berlaku sepuluh sampai lima belas tahun bagi parpol yang dibubarkan akibat korupsi.

Terkait dengan ini, sebenarnya Pasal 10 Peraturan Mahkamah Konstitusi No. 12 Tahun 2008 tentang Prosedur Beracara dalam Pembubaran Partai Politik sudah mengatur bahwa terhadap parpol yang telah dibubarkan diberlakukan pelarangan terhadap mantan pengurus parpol yang dibubarkan untuk melakukan kegiatan politik. Namun norma ini masih terdapat kekurangan, terutama untuk parpol yang dibubarkan akibat tindak pidana korupsi. Pertama, tidak ada larangan untuk mendirikan parpol baru. Kedua, aturannya masih di level Peraturan MK. Oleh karena itu, normanya perlu dikonstruksikan ulang dan levelnya dinaikkan ke level UU Parpol yang berkaitan dengan syarat pembentukan Parpol.

Saat ini syarat untuk mendirikan partai baru sebagaimana diatur dalam Pasal 2 UU Parpol hanya mengatur larangan terhadap pendiri dan pengurus terkait dengan rangkap jabatan. Pasal 2 ayat (1b) menyebut "Pendiri dan pengurus Partai Politik dilarang merangkap sebagai anggota Partai Politik lain". Terkait larangan ini, perlu ditambah satu ayat lagi yang menyatakan bahwa "pendiri dan pengurus parpol tidak boleh berasal dari parpol yang telah dibubarkan berdasarkan putusan pengadilan yang berkekuatan hukum tetap". Hal ini tentu bisa dilakukan karena hak politik adalah derogable right sehingga dapat dikurangi atau dibatasi pemenuhannya oleh negara dalam keadaan tertentu. Dengan demikian, kekhawatiran bahwa pengurus yang partainya dibubarkan akan berpindah atau mendirikan partai baru bisa terjawab dan efektifitas penghukuman terhadap parpol dapat terpenuhi.

\section{Penutup}

\section{Kesimpulan}

Berdasarkan penelitian yang dilakukan maka dapat disimpulkan menjadi 3 hal. Pertama, terdapat 8 kasus korupsi yang mengarah pada pengaliran dana hasil korupsi ke parpol, baik yang 
melibatkan ketua umum, pengurus maupun anggota parpol.

Kedua, telah banyak regulasi yang diorientasikan pada upaya mendorong parpol bebas korupsi. Akan tetapi pada kenyataannya korupsi yang melibatkan partai masih terjadi dan belum ada penegakan hukum yang mapan atasnya.

Ketiga, adanya kesepahaman parpol masuk kategori korporasi sehingga desain penegakan yang dibangun dapat diterapkan sesuai harapan. Adapun desain penegakan hukum korupsi parpol ke depan perlu diterapkan dengan tiga tingkatan, yaitu: 1) pengurangan bantuan keuangan negara terhadap parpol (maksimal 30\% pada 1 tahun anggaran); 2) larangan menjadi peserta pemilu (dilakukan pada periode penyelenggaraan pemilihan selanjutnya dalam semua tingkatan pemilihan); dan 3) pembubaran parpol yang diikuti pembatasan hak mantan pengurus parpol untuk melakukan kegiatan berbasis politik termasuk berpindah ke partai lain atau mendirikan parpol baru.

\section{Saran}

Dengan adanya pemahaman bahwa parpol masuk kategori korporasi, maka pertama, jaksa dan hakim perlu berani melakukan tafsir luas dan progresif terhadap parpol sebagai korporasi untuk dapat menjerat parpol sebagai subjek tipikor jika terbukti keterlibatannya. Hal ini perlu dilakukan sebagai langkah pertama dan utama dalam menerapkan gagasan desain penegakan hukum korupsi parpol.

Kedua, pidana tambahan yang diberikan hakim bisa dalam bentuk pengurangan bantuan keuangan negara terhadap parpol, larangan menjadi peserta pemilu, atau pembubaran parpol.

Ketiga, konkritkan desain penegakan hukum korupsi parpol melalui jalur legislasi untuk mendapatkan kepastian bentuk penghukuman. Hal ini dapat dilakukan dengan memasukkan secara tegas bahwa parpol adalah korporasi yang mempunyai corak khusus dan memasukkan desain penegakan hukum yang telah digagas dalam penelitian ini ke dalam undang-undang parpol. Walaupun hal ini terlihat utopis karena undangundang adalah produk politik dan elit politik tidak mungkin menjerumuskan dirinya sendiri dengan perubahan tersebut. Akan tetapi, demi membangun idealitas kebijakan pidana dalam bangunan negara hukum, jalur legislasi ini tetap perlu dicoba apalagi jika nanti telah ada putusan hakim yang mendahuluinya.

\section{Referensi}

Ali, Mahrus. (2016), Hukum Pidana Korupsi. UII Press. Yogyakarta.

Ananda, Putra. Kemendagri Berupaya Tambah Bantuan Dana Parpol, https://mediaindonesia.com/read/ detail/274450-kemendagriberupaya-tambah-bantuan-danaparpol. 18 Agustus 2020.

Aspan, Zulkifli dan Wiwin Suwandi. (2020). Menjerat Kader, Melepas Partai Politik Pertanggungjawaban Pidana Partai Politik Dalam Kasus Tipikor. Jurnal Al - Adalah: Jurnal Hukum dan Politik Islam 5(1): 7090.

Asyhadie, Zaeni dan Arief Rahman. (2014). Pengantar Ilmu Hukum. PT. Rajagrafindo Persada. Jakarta.

BBC News Indonesia. Korupsi Massal di DPRD. https://www.bbc.com/ indonesia/indonesia-45464288. 15 Mei 2020 (21:17).

Detik News. 2 Tahun Lebih PK Anas Urbaningrum Belum Diputus, Ini Kata MA. https://news.detik.com/berita/d5131246/2-tahun-lebih-pk-anas- 
urbaningrum-belum-diputus-inikata-ma. 18 Agustus 2020 (20:11).

Hariadi, Tunjung Mahardika. (2013). Perbandingan Penanganan Tindak Pidana Korupsi di Negara Singapura dan Indonesia. Jurnal Recidive 2(3): 265-279.

Hiariej, Eddy OS, Korupsi Partai Politik. https://nasional.kompas.com/read /2011/08/03/03203925/korupsi.p artai.politik?page=all. 15 Mei 2020 (17:02).

Hukum Online. Mungkinkah Partai Politik diperlakukan sebagai Korporasi Kasus Tipikor? https://www.hukumonline.com/be rita/baca/lt5ba0c9cc5e3cf/mungk inkah-partai-politik-diperlakukansebagai-korporasi-dalam-kasustipikor?page $=2 . \quad 16 \quad$ Mei 2020 (20:00).

Hukum Online. Vonis Diperberat dan Hak Politik Dicabut, Suryadharma Ali Tak Akan Kasasi, https://www.hukumonline.com/be rita/baca/lt57503d2629d64/vonis -diperberat-dan-hak-politikdicabut--suryadharma-ali-takakan-kasasi/. 18 Agustus 2020 (20:57).

Irawan, Ade dkk. (2014). Panduan Pemantauan Korupsi Pemilu, Indonesia Corruption Watch. Jakarta.

Junaidi, Veri, dkk. (2011). Anomali Keuangan Partai Politik Pengaturan dan Praktek. Kemitraan bagi Pembaruan Tata Pemerintahan. Jakarta.

Komisi Pemberantasan Korupsi. (2018). Buku Panduan Sistem Integritas Partai Politik. Jakarta

Komisi Pemberantasan Korupsi. Perkara Berkekuatan Hukum Tetap (Inkracht) 2015. https://www.kpk.go.id/id/publikas i/penanganan-

perkara/inkracht/467-inkracht2015. 18 Agustus 2020 (20:31).

Komisi Pemberantasan Korupsi. Perkara berkekuatan Hukum tetap (Inkracht) 2018. https://www.kpk.go.id/id/publikas i/penangananperkara/inkracht/603inkracht2018. 19 Agustus 2020 (16:20).

Komisi Pemberantasan Korupsi. Statistik TPK Berdasarkan Profesi/Jabatan. https://www.kpk.go.id/id/statistik /penindakan/tpk-berdasarkanprofesi-jabatan. 11 Juli 2020 (19:05).

Kompas, Parpol Peserta Pemilu 2019 Sepakati Sistem Integritas Partai Politik. https://nasional.kompas.com/read /2018/12/04/16571931/parpolpeserta-pemilu-2019-sepakatisistem-integritas-partaipolitik?page=all. 23 Agustus 2020 (17:52).

Kompas. Perjalan Kasus PLTU Riau 1 Jerat Eni Maulani Saragih Hingga Sofyan Basir, https://nasional.kompas.com/read /2019/04/24/06590331/perjalana n-kasus-pltu-riau-1-jerat-enimaulani-saragih-hingga-sofyanbasir?page=all. 19 Agustus 2020 (17:21).

Kompas. Upaya Memutus Aliran Dana Korupsi ke Partai Politik. https://nasional. kompas.com $/ \mathrm{read} / 2017 / 06 / 12 / 07$ 010051/upaya.memutus.aliran.dan a. korupsi.ke.partai.politik.?page $=a l$ l. 19 Agustus 2020 (19:45).

Liputan 6. Vonis 8 Tahun Bui Untuk Anas Urbaningrum 5 tahun Silam. https://www.liputan6.com/news/r ead/4069279/vonis-8-tahun-buiuntuk-anas-urbaningrum-5-tahunsilam. 18 Agustus 2020 (21:21). 
Lodder, Suzanne. (2017). "The Dutch Public Prosecutor's Transaction Policy for Fraudulent Companies in a Comparative Law Perspective". Thesis. International Business Law \& Rechtsgeleerdheid, Tilburg University.

Mardiastuti, Aditya. Pemerintah Terbitkan PP Kenaikan Dana Parpol 10 Kali Lipat.

https://news.detik.com/berita/d3809451/pemerintah-terbitkanpp-kenaikan-dana-parpol-10-kalilipat. 23 Agustus 2020 (21:00)

Marzuki, Peter Mahmud. (2008). Penelitian Hukum, Cet. 2. Kencana. Jakarta.

Mochtar, Zainal Arifin. (2019). Pertanggungjawaban Partai Politik yang melakukan Tindak Pidana Korupsi. Jurnal Mimbar Hukum 31(2): 157-173.

Muhammad, Abdulkadir. (2004). Hukum dan Penelitian Hukum, Cet. 1. PT. Citra Aditya Bakti. Bandung.

Muladi dan Dwidja Priyatno. (2010). Pertanggungjawaban Pidana Korporasi. Kencana Prenada Media. Jakarta.

Mulyadi, Lilik. (2008). Bunga Rampai Hukum Pidana: Perspektif, Teoritis, dan Praktik. Alumni. Bandung.

Nasional, Artidjo CS Vonis Anas Urbaningrum 14 Tahun Penjara. https://nasional.okezone.com/read /2015/06/08/337/1162175/artidj o-cs-vonis-anas-urbaningrum-14tahun-penjara. 18 Agustus 2020 (20:19).

Perdana, Adhitya, et.al. (2018). Pembiayaan Pemilu di Indonesia. Bawaslu RI. Jakarta.

Ristianto, Christoforus. Auditor Diminta Cermati Titik Kerawanan Manipulasi Dana Kampanye. https://

nasional.kompas.com/read/2019/

05/02/09515391/auditor-diminta-

cermati-titik-kerawanan-

manipulasi-dana-kampanye. 19

Agustus 2020 (21:21).

Safa'at, Muchamad Ali. (2011). Pembubaran Partai Politik, Pengaturan dan Praktik Pembubaran Partai Politik dalam Pergulatan Republik., Raja Grafindo. Jakarta.

Soleh, Muhammad Faisol. (2018). "Tinjauan Hukum Pidana terhadap Partai Politik sebagai Korporasi dalam Tindak Pidana Korupsi dan Tindak pidana Pencucian Uang". Skripsi. Fakultas Hukum Universitas Islam Indonesia.

Suparman, Fana. Sistem Politik Membuka Ruang Korupsi. https://www.beritasatu.com/yudodahono/nasional/524403/sistempolitik-membuka-ruang-korupsi. 23 Agustus 2020 (21:23).

Surbakti, Ramlan dan Didik Supriyanto. (2011). Pengendalian Keuangan Partai Politik. Kemitraan bagi Pembaruan Tata Pemerintahan. Jakarta.

Tempo. Setya Novanto Ajukan PK dalam Kasus E-KTP. https://nasional.tempo.co/read/12 41080/setya-novanto-ajukan-pkdalam-kasus-e-ktp/full\&view=ok. 19 Agustus 2020(16:27).

United States Sentencing Commission, Guidline Manual, November 1, 2016.

Wangga, Maria Silvya E. (2018). Pertanggungjawaban Pidana Partai Politik sebagai Badan Hukum dalam Tindak Pidana Korupsi.Jurnal Integritas 4(2): 255-278. 
Agil Oktaryal, Proborini Hastuti 